EVALUASI, 3(1), Maret 2019, ISSN 2580-3387 (print) |ISSN 2615-2886 (online)

Homepage : http://e-journal.staima-alhikam.ac.id/index.php/evaluasi

DOI $\quad$ : http://doi.org/10.32478/evaluasi.v3i1.225

Article type : Review Article

\title{
KONSEP KEPEMIMPINAN PERSPEKTIF TASAWUF POSITIF MODERN
}

\section{Ahmad Buchori Muslim \\ Dosen Sekolah Tinggi Ilmu Tarbiyah (STIT) Islamic Village Tangerang}

\begin{abstract}
Sufism as the core of Islamic teachings emerged by providing solutions and therapies for human problems by bringing closer to Allah the Creator. However, Sufism has been perceived as an inner practice that detaches itself from the world. However, lately, there is an understanding of Sufism which does not make its practitioners withdraw from the environment and instead requires its practitioners to go down to the community and contribute to solving problems faced by their communities. Sufism is known as "Positive Sufism" or neo-Sufism. Positive Sufism is a turning point of conservative Sufism. If conservative Sufism suggests that Sufism surges, then positive Sufism gives the impression that Sufism must be grounded. It must appear in all social life, and also contribute to solving world problems. This includes issues regarding leadership. The study method used is qualitative, the method of presenting the data is descriptive analysis, and it is designed with a library approach that explores some of the literature relating to the discussion of leadership concepts of modern positive Sufism perspectives. Therefore reviewing the concept of leadership and the criteria of a leader in the realm of Sufism is an alternative that can be done. So that it is expected to give an alternative picture like a leader who wants to run the wheel of his leadership based on Sufi souls, a Sufism expert.
\end{abstract}

Keywords: Modern Positive Sufism, Leadership

\section{ABSTRAK}

Tasawuf sebagai inti ajaran Islam muncul dengan memberi solusi dan terapi bagi problem manusia dengan cara mendekatkan diri kepada Allah yang Maha Pencipta. Akan tetapi, tasawuf selama ini dipersepsikan sebagai laku batin yang melepaskan diri dari keduniaan. Akan tetapi, belakangan terdapat suatu paham tasawuf yang tidak menjadikan pengamalnya menarik diri dari lingkungan dan justru mengharuskan pengamalnya untuk turun ke masyarakat dan ikut berkontribusi dalam pemecahan masalah yang dihadapi masyarakatnya. Tasawuf ini dikenal dengan istilah "Tasawuf Positif" atau 
neo-sufism. Tasawuf positif merupakan titik balik dari tasawuf konservatif. Jika tasawuf konservatif mengesankan tasawuf itu melangit, maka tasawuf positif memberikan kesan bahwa tasawuf itu harus membumi. Harus nampak dalam segala kehidupan sosial, dan juga ikut andil dalam penyelesaian permasalahan dunia. Termasuk didalamnya adalah permasalahan mengenai kepemimpinan. Metode Kajian yang digunakan adalah kualitatif, metode penyajian datanya adalah deskriptif analisis, serta dirancang dengan pendekatan kepustakaan yang menelusuri beberapa literatur yang berkaitan dengan pembahasan tentang konsep kepemimpinan perspektif tasawuf positif modern. Oleh karenanya mengkaji konsep kepemimpinan dan kriteriakriteria seorang pemimpin dalam ranah ajaran tasawuf adalah sebuah alternatif yang dapat dilakukan. Sehingga diharapkan memberikan gambaran alternatif bagai seorang pemimpin yang ingin menjalankan roda kepemimpinanya berdasarkan jiwa-jiwa sufi seorang ahli tasawuf.

Kata Kunci : Tasawuf Positif Modern, Kepemimpinan

\section{A. LATAR BELAKANG}

Berkembangnya ilmu pengetahuan dan teknologi dewasa ini, membawa dampak yang begitu besar terhadap tatanan kehidupan yang ada. Manusia kini mampu berkomunikasi tanpa harus dibatasi oleh ruang dan waktu. Bukan menjadi hal yang luar biasa lagi untuk saat ini, mengetahui apa yang terjadi dibelahan dunia lainnya hanya dengan alat yang begitu sederhana yang dilengkapi dengan jaringan internet. Lebih dari itu, berbagai inovasi-inovasi terbaru pun seperti tunas-tunas yang bermunculan saat bumi mulai tersirami air hujan setelah melewati masa kemarau. Inovasi-inovasi itu pun semakin memanjakan manusia dalam menjalai hidup dan kehidupannya.

Memang, di satu sisi perkembangan tersebut memberikan kemudahan-kemudahan bagi manusia. Namun, bukan berarti tidak ada dampak negatif yang timbul bersamanya. Perkembangan ilmu pengetahuan dan teknologi ini juga sangat rentan menjadikan manusia menjadi manusia yang tidak bermoral. Dengan memanfaatkan teknologi cyber, siapa saja mampu mengakses informasi-informasi positif atau negatif sekaligus. Diantara informasi negatif tersebut adalah free sex, narkoba, Human Trafficking dan lain sebagainya kini sudah bisa diakses dengan mudahnya melalui jaringan internet. Itu hanya sebagian kecil dari dampak negatif akibat adanya perkembangan ilmu pengetahuan dan teknologi. 
Meskipun perkembangan yang terjadi selama ini nampak begitu membanggakan, di mana sesuatu yang beberapa tahun yang lalu nampak mustahil, kini bisa terealisasikan, bahkan terkadang realitanya jauh melebihi yang dibanyangkan. Akan tetapi, justru kondisi ini ternyata tidak selamanya memberikan kenyamanan, tetapi justru melahirkan abad kecemasan (the age of anxienty). Kemajuan ilmu dan teknologi hasil karya cipta manusia yang memberikan segala fasilitas kemudahan, ternyata juga memberikan dampak - selain problem di atas - berbagai problema psikologis bagi manusia itu sendiri. Masyarakat modern kini sangat mendewa-dewakan ilmu pengetahuan dan teknologi, sementara pemahaman keagamaan yang didasarkan pada wahyu sering ditinggalkan dan hidup dalam keadaan sekuler (pemisahan agama dengan aspek kehidupan lainnya). Agama dianggap tudak memiliki relevansi lagi dalam masa kini yang telah banyak berkembang.

Tidak kalah mencengangkan, fenomena-fenomena perebutan kekuasan pun menggejala di era modern ini. Karena kekuasaan dinilai sebagai lading yang cukup menjanjikan untuk menambah pundi-pundi materi. Jual beli kekuasaan pun menjadi jawaban. Beratus-ratus juta, bahkan sampai bertrilyun-trilyunan rela dikeluarkan agar dapat menjadi penguasa (pemimpin). Hal ini pada akhirnya menjadikan kepemimpinannya berlandaskan pada materi. Setidaknya pemimpin ini akan memikirkan bagaimana modal yang ia keluarkan dalam suksesi kepemimpinannya dapat kembali, setelah itu baru dipikirkan bagaimana caranya agar ia dapat meraih banyak keuntungan saat ia memimpin nanti. Pemimpin seperti ini tidak memntingkan lagi apa itu kesejahteraan rakyat yang ia pimpin, bahkan sebaliknya demi meraih keuntungan ia tega menelantarkan rakyatnya. Penggelapan dana, pengadayaan proyek fiktif, dan tingkah laku negative lainnya telah menjadi potret suram kepemimpinan. Dan parahnya lagi, mereka para pemimpin itu juga mengaku beragama. Mereka juga sholat, puasa dan bahkan naik haji. Tapi nyatanya laku yang ditampilkan tidak mencerminkan laku seorang pemimpin yang bergama. Beragama menjadi sesuatu yang dlahir saja, tidak ada internalisasi nilai agama dalam kesehariannya.

Tasawuf sebagai inti ajaran Islam muncul dengan memberi solusi dan terapi bagi problem manusia dengan cara mendekatkan diri kepada Allah yang Maha Pencipta. Selain itu berkembang pula kegiatan konseling yang memang bertujuan membantu seseorang menyelesaikan masalahnya. Karena semua masalah pasti ada penyelesaiannya serta segala penyakit pasti ada obatnya. Peluang tasawuf dalam menangani penyakit-penyakit psikologis atas segala problem manusia, semakin 
terbentang lebar di era modern ini. ${ }^{1}$ Akan tetapi, tasawuf selama ini dipersepsikan sebagai laku batin yang melepaskan diri dari keduniaan. Seorang sufi akan tercemar jika ia masuk pada dunia politik misalnya. Begitu pun dalam kepemimpinan yang saat ini sarat dengan keduniaan. Akan tetapi, belakangan terdapat suatu paham tasawuf yang tidak menjadikan pengamalnya menarik diri dari lingkungan dan justru mengharuskan pengamalnya untuk turun ke masyarakat dan ikut berkontribusi dalam pemecahan masalah yang dihadapi masyarakatnya. Tasawuf ini dikenal dengan istilah "Tasawuf Positif" atau neo-sufism dalam terminology Fazlur Rahman.

Berangkat dari fakta di atas, maka dalam tulisan ini akan dibahas terkait dengan Tasawuf Positif yang kemudian ditarik ke dalam ranah kepemimpinan. Dalam arti seorang pemimpin yang mengamalkan laku Tasawuf Positif ini.

\section{B. PENDEKATAN DAN JENIS KAJIAN}

Metode Kajian yang digunakan adalah kualitatif, metode penyajian datanya adalah deskriptif analisis, serta dirancang dengan pendekatan kepustakaan yang menelusuri beberapa literatur yang berkaitan dengan pembahasan tentang konsep kepemimpinan perspektif tasawuf positif modern.

\section{PEMBAHASAN}

\section{Tasawuf dan Sejarah Perkembangannya}

Konsep kualifikasi modern itu memiliki konotasi yang jauh lebih penting karena mengisyaratkan adanya perbedaan dengan tasawuf pada masa-masa sebelumnya. Ciri pembeda utama adalah waktu yang menunjuk pada konteks social keagamaan masing-masing. Sebagai suatu setting social, perbedaan konteks ini menimbulkan konsekuensi perbedaan susunan masyarakat dan struktur keberagaman warga dan akhirnya keberbedaan problem social yang memerlukan pola pemecahannya masinh-masing. Akan tetapi unsur essensial yang tidak mungkin dikesampingkan adalah bingkai keberagaman yang harus tetap berada dalam lingkungan Al-Qura'an dan As-Sunnah. Meskipun visi religious dalam melihat manusia modern lebih menekankan pada esensi perilaku dalam hubungannya dengan alam, manusia dengan Tuhan, namun sosok dunia modern

1 Ahmad Suyuti, Percik-Percik Kesufian, (Bandung: Penerbit Pustaka Hidayah, 2002), hlm. 93 
dapat diamati dalam dunia literatur yang lainnya. ${ }^{2}$ Profil masyarakat modern sendiri ialah sebuah masyarakat dengan budaya industrinya, yaitu masyarakat yang mengembangkan cara pikir ilmiah. ${ }^{3}$

\section{a. Pengertian Tasawuf}

Sebagai sistem ajaran keagamaan yang lengkap dan utuh, Islam memberi tempat kepada jenis penghayatan keagamaan eksoterik (zhahiri, lahiri) dan esoteric (bathini, batini) sekaligus. Namun dalam kenyataannya, tidak sedikit kaum muslim yang penghayatan ke-Islamannya lebih mengarah kepada yang lahiri, begitu pun sebaliknya. Bagi mereka yang lebih menitikberatkan perhatian pada segi-segi syari'ah atau hukum adalah kaum syari'ah yang juga sering disebut dengan kaum lahiri. Adapun bagi mereka yang berkecimpung dalam amalan-amalan tarikat disebut sebagai kaum batini. ${ }^{4}$ Bagi golongan terakhir ini juga berhubungan dengan tasawuf. Dimana menurut ajaran tasawuf sendiri, satu-satunya cara untuk menjadi Manusia Sempurna ${ }^{5}$ adalah dengan mengikuti tarikat sufi. ${ }^{6}$

Pada kenyataannya, tasawuf merupakan nama yang tidak memuaskan dan seringkali kontroversial yang mulai diterapkan pada berbagai manifestasi sosial dan institusional dari realitas batin keyakinan Islam. Ia adalah sebuah nama yang dihormati sekaligus juga ditentang oleh sebagian lainnya. Meskipun demikian, sudah cukup banyak yang membahas ihwal ini. Untuk menghampiri dan memahami hlm. 10

${ }^{2}$ Muhammad Sholikhin, Tasawuf Aktual, (Semarang: Pustaka Nuun, 2004),

${ }^{3}$ Abdul Muhayya. Peranan Tasawuf dalam Menanggulangi Krisis Spiritual. Dalam Bima Bayu A., Tasawuf dan Krisis, (Yogyakarta: Pustaka Pelajar, 2001), hlm. 11

${ }^{4}$ Ali Maksum, Tasawuf sebagai Pembebasan Manusia; Telaah Signifikansi Konsep "Tradisionalisme Islam” Sayyed Hossein Nasr, (Yogyakart: Pustaka Pelajar, 2003), hlm. 105

5 Manusia sempurna ini merupakan definisi dari seorang sufi. Lihat Muhammad Zaki Ibrahim, Tasawuf Salafi, Menyucikan Tasawuf dari Noda-noda, (Jakarta: Hikmah, 2002), hlm. 8

${ }^{6}$ Zainul Kamal. Tasawuf dan Tarekat: Ajaran Esoterisme Islam. Dalam Ahmad Najib Burhani, ed., Manusia Modern Mendamba Allah: Renungan Tasawuf Modern, (Jakarta: Penerbit IIman \& Penerbit Hikmah, 2002), hlm. 13 
hakikatnya, kita perlu memperhatikan berbagai istilah dan deskripsi lain. ${ }^{7}$

Dalam kajian ilmiah, harus dibedakan antara tasawuf dengan ilmu tasawuf. Tasawuf berarti kesadaran seorang hamba, sadar akan adanya dialog dan komunikasi langsung dengan Tuhan. Dengan adanya kesadaran ini, berimplikasi pada kecenderungan bertingkah laku yang baik terhadap Tuhan, diri sendiri, sesama manusia, dan terhadap alam semesta. Sedangkan ilmu tasawuf ialah hasil atau produk sejarah, yang merupakan hasil ijtihad ulama sufi tentang bagaimana cara untuk mendekatkan (taqqrub), berkomunikasi dan berdialog dengan Tuhan. ${ }^{8}$

Kembali kepada pengertian tasawuf, Zakaria al-Anshari, seperti yang dikutip oleh Nasaruddin, ${ }^{9}$ menyebutkan bahwa tasawuf sebagai ilmu tentang kebersihan jiwa, perbaikan budi pekerti serta pembangunan lahir dan batin guna memperoleh kebahagiaan abadi. Dengan redaksi yang berbeda, Al-Taftazani dalam Abdul Muhayya, ${ }^{10}$ mendefinisikan tasawuf sebagai suatu moralitas berdasarkan Islam (adab). Karena itu, seorang sufi adalah mereka yang bermoral, sebab semakin ia bermoral semakin bersih dan bening (shafa) jiwanya. Dengan pengertian bahwa tasawuf adalah moral, maka tasawuf adalah semangat inti Islam. Sebab, ketentuan Hukum Islam berdasarkan landasan moral islami. Oleh karena itu, hukum Islam tanpa tasawuf ibarat badan tanpa nyawa atau wadah tanpa isi.

Kemudian, terdapat pula pendefinisian tasawuf yang berpijak pada tiga sudut pandang: Pertama, sudut pandang manusia sebagai makhluk terbatas. Disini, tasawuf didefinisikan sebagai upaya mensucikan diri dengan cara menjauhkan pengaruh kehidupan dunia dan memusatkan perhatian hanya kepada Allah SWT. Kedua, sudut pandang manusia sebagai makhluk yang harus berjuang. Berangkat

7 William C. Chittick, Tasawuf di Mata Kaum Sufi, terj. Zainul Am, (Bandung: Mizan, 2002), hlm. 69

${ }^{8}$ M. Amin Syukur, Tasawuf Kontekstual; Solusi Problem Manusia Modern, (Yogyakarta: Pustaka Pelajar, 2003), hlm. 86

${ }^{9}$ Nasaruddin Umar, Tasawuf Modern, (Jakarta: Republika, 2014), hlm. 2

${ }^{10}$ Abdul Muhayya, Op. Cit., hlm. 23 
dari sudut pandang ini, tasawuf didefinisikan sebagai upaya memperintah diri dengan akhlak yang bersumber dari ajaran agama dalam rangka mendekatkan diri kepada Allah SWT. Ketiga, sudut pandang manusia sebagai makhluk yang berTuhan, yang memunculkan definisi tasawuf sebagai kesadaran fithrah (ke-Tuhanan) yang dapat mengarahkan jiwa agar tertuju kegiatan-kegiatan yang dapat menghubungkan manusia dengan Tuhan. ${ }^{11}$

Sementara itu, pemilihan istilah tasawuf sendiri terdapat beberapa perbedaan pendapat. Beberapa berpendapat bahwa kata tasawuf dinisbahkan kepada perkataan ahl alshuffah. ${ }^{12}$ Ada yang mengatakan dari kata "shuf" (bulu domba), "shof" (barisan), "shafa" (jernih), dan kata "shuffah" (emper masjid Nabi yang ditempati oleh sebagian sahabat Nabi saw.). ${ }^{13}$

Ahl al-Shuffah adalah sebuah komunitas yang memiliki karakteristik yang menyibukkan diri dengan kegiatan ibadah dengan tidak membuang-buang waktu dengan siasia.Mereka meninggalkan kehidupan dunia, dengan memilih pola hidup zuhud. ${ }^{14}$ Mereka mengambil sesuatu yang bersifat duniawi sebatas menutupi tubuh dan menenangkan perutnya yang lapar.Ahl al-Shuffah juga berarti orang-orang yang ikut pindah dengan Nabi dari Mekkah ke Madinah, dan karena kehilangan harta, berada dalam keadaan miskin dan tak mempunyai apa-apa. Mereka tinggal di Masjid Nabi dan

${ }^{11}$ H.M. Jamil, Cakrawala Taswuf: SEjarah, Pemikiran dan Kontekstualitas, (Ciputat: Gaung Persada Press, 2004), hlm. 7

${ }^{12}$ Ibid., hlm. 1

${ }^{13}$ M. Amin Syukur, Tasawuf Sosial, (Yogyakarta: Pustaka Pelajar, 2004),

hlm. 4

${ }^{14}$ Oleh sekelompok Muslim diartikan dengan asketisme.Pada mulanya asketisme merupakan sikap baiawarawan atau para rahib yang menyangkal kehidupan dunia dengan harapan bisa menyucikan diri dan kemudian bisa bertemu dengan Tuhan. Lihat Haidar Bagir. Manusia Modern Mendamba Allah (Pengantar). Dalam Ahmad Najib Burhani, Manusia Modern Mendamba Allah, Renungan Tasawuf Positif, (Jakarta: Penerbit IIMan dan Penerbit Hikmah, 2002), hlm.Xv. Zuhud ini adalah hasil dari wara', yaitu selalu mengambil sesuatu yang jelas-jelas hala dan meninggalkan segala sesuatu yang diragukan kehalalannya. Lihat Said Agil Siradj, Syariat sebagai Unsur Integral Tasawuf. Dalam Ahmad Najib Burhani, ed., Manusia Modern Mendamba Allah: Renungan Tasawuf Modern, (Jakarta: Penerbit IIman \& Penerbit Hikmah, 2002), hlm. 249-250 
tidur di atas bangku batu dengan memakai pelana sebagai bantal. ${ }^{15}$

\section{b. Sejarah Perkembangan Tasawuf}

Jika menengok sejarah hidup nabi Muhammad SAW., maka tidak akan ditemukan istilah tasawuf. Karena memang tasawuf atau sufisme adalah satu cabang keilmuan dalam Islam yang lahir kemudian setelah Rasulullah wafat. Karena tidak memiliki akar dalam ajaran Islam dan sejarah nabi Muhammad SAW. inilah, maka menurut ulama zhahiri (lahiri) dianggap sebagai bid'ah terhadap ajaran Islam, dan menganggapnya sebagai hasil dari bekerjanya kekuatankekuatan pengaruh Kristen, Hindu, Buddha, dan Persia. ${ }^{16}$

Menurut Hakim Hassan dalam al-Thashawwuf fi Syi'ri al'Arab, istilah tasawuf baru terdengar pada pertengahan abad kedua. ${ }^{17}$ Meskipun sebagian lainnya berpendapat bahwa kaum muslimin mengenal tasawuf setelah abad ketiga Hijriyah, pernyataan tersebut merupakan kebohongan terhadap sejarah. ${ }^{18}$

Istilah sufi sendiri, pertama kali digunakan oleh Abu Hasyim, seorang zahid dari Syria (W.780 M). ${ }^{19}$ Meskipun sebagian sejarawan mengaitkan sejarah tasawuf ini dengan Imam Ja'far al-Shadiq bin Muhammad al-Baqir bin 'Ali Zayn al'Abidin bin Husayn bin 'Ali bin Abi Thalib. ${ }^{20}$ Terlepas dari siapa yang pertama mengenalkan atau menggunakan istilah tasawuf, perkembangan tasawuf sebagai semacam suatu disiplin sejak abad kedua Hijriyah ini dibawa oleh pribadi-

${ }^{15}$ H.M. Jamil, Op. Cit., hlm. 2

${ }^{16}$ Haidar Bagir. Antara Tasawuf Eksesif dan Tasawuf Positif (Pengantar). Dalam Ahmad Najib Burhani, Sufisme Kota, (Jakarta: Serambi Ilmu Semesta, 2001), hlm. Vii hlm. 3

${ }^{17}$ M. Amin Syukur, Tasawuf Sosial, (Yogyakarta: Pustaka Pelajar, 2004),

18 Muhammad Zaki Ibrahim, Tasawuf Salafi, Menyucikan Tasawuf dari Noda-noda, (Jakarta: Hikmah, 2002), hlm. 15

${ }^{19}$ H. Wilberforce-Clarke. Pendahuluan. Dalam Syihabuddin Umar ibn Muhammad Suhrawardi, 'Awarif al-Ma'arif: Sebuah Buku Daras Klasik Tasawuf, terj. Ilma Nugrahani Ismail, (Bandung: Pustaka Hidayah, 1998), hlm. 14

${ }^{20}$ Haidar Bagir. Antara Tasawuf Eksesif dan Tasawuf Positif (Pengantar). Op. Cit., hlm. vi 
pribadi seperti al-Hasan al-Bahsry, Sufyan at-Tsawriy, alHarits al-Muhasibi, Yazid al-Busthami, dan sebagainya. ${ }^{21}$

Terlepas dari siapa yang pertama mengenalkan tasawuf atau siapa yang pertama kali mengembangkannya, tasawuf selalu dipersepsikan sebagai ajaran yang menuntut pengamalnya untuk tidak terlalu larut dalam keduniaan. Bahkan sampai pada taraf tertentu, seorang sufi harus mengasingkan diri dari kehidupan dunia dan menyerahkan kehidupannya kepada Allah SWT. secara mutlak. Dari sudut pandang tokoh tasawuf ini (mistik), pengasingan ini dalam rangka menyucikan diri, membersihkan jiwa dari keterikatan akan kenikmatan materi. $^{22}$

\section{Tasawuf Positif di Era Modern}

Sebelum membahas Tasawuf Positif di era modern ini, perlu kiranya dipahami terlebih dahulu apa itu modern. Kata modern bisa digunakan untuk memberi predikat kepada seseorang, waktu, seni, benda, pemikiran, kebudayaan dan tingkah laku. Gagasan modern ini sering dipahami sebagai gagasan pembaharuan dan dipertentangkan dengan gagasan tradisional. $^{23}$ Selanjutnya, modernisme yang merupakan era dari modern itu sendiri diawali oleh Descartes dan Newton yang darinya lahir suatu pandangan hidup yang mekanistik dan atomic. la tergambar dengan kemajuan teknologi dan pesatnya industrialisasi. ${ }^{24}$ Era modern ini, ditandai dengan dua hal, yaitu: (1) penggunaan teknologi dalam berbagai aspek kehidupan manusia; (2) berkembangnya intelektual sebagai wujud dari kemajuan intelektual manusia. $^{25}$

Dalam psikologi agama, disebutkan bahwa berangkat dari sikap dan tingkah laku yang tampak, kaum sufi cenderung menampilkan perilaku yang terkesan aneh. Dalam rangka penyucian jiwa (batin)

${ }^{21}$ Haidar Bagir. Antara Tasawuf Eksesif dan Tasawuf Positif (Pengantar). Op. Cit., hlm. vii

Jalaluddin, Psikologi Agama: Memahami Perilaku dengan Mengaplikasikan Prinsip-prinsip Psikolgi, cet. 16, (Jakarta: Rajagrafindo Persada, 2012), hlm. 134

${ }^{23}$ Achmad Mubarak, Relevansi tasawuf dengan Problem Kejiwaan Manusia Modern. Dalam Ahmad Najib Burhani, ed., Manusia Modern Mendamba Allah: Renungan Tasawuf Modern, (Jakarta: Penerbit IIman \& Penerbit Hikmah, 2002), hlm. 167 2001), hlm. 177

${ }^{24}$ Ahmad Najib Burhani, Sufisme Kota, (Jakarta: Serambi Ilmu Semesta,

${ }^{25}$ Achmad Mubarak, Op. Cit. hlm. 167 
misalnya, kaum sufi berusaha untuk berpantang diri dari dosa. Karenanya, terkadang merekapun terpaksa membatasi pergaulan dengan masyarakat, karena khawatir akan terpengaruh oleh kecenderungan perbuatan dosa. Yang pada akhirnya terkesan bahwa kaum sufi mengisolasikan (menarik) diri dari kehidupan masyarakat. ${ }^{26}$ Bahkan menurut psikologi agama, penarikan diri dari kehidupan sosial ini dengan cara mengasingkan diri ini dijumpai pula pada penderita gangguan jiwa. Karena ada kesamaan sikap dan perilaku keagamaan tokoh-tokoh mistik dengan pengidap gangguan jiwa. ${ }^{27}$ Laku tasawuf yang demikian itu akhirnya menjadikan ia tidak membumi, dan hanya melangit. Dalam arti hanya bercengkrama dengan Sang Pencipta tanpa mau berinteraksi dengan ciptaan-Nya.

Pada abad XXI ini dengan segala permasalahannya yang begitu kompleks, ${ }^{28}$ tasawuf dituntut untuk lebih humanistik, empirik, dan fungsional. Penghayatan terhadap ajaran Islam bukan hanya reaktif, tetapi juga aktif serta memberikan arah kepada sikap manusia di dunia ini. ${ }^{29}$ Sehingga seorang sufi tidak lagi mengasingkan diri dari dunia luar, melainkan ikut berperan aktif dalam pemecahan

${ }^{26}$ Jalaluddin, Op. Cit., hlm. 146

${ }^{27}$ Ibid., hlm. 134

${ }^{28}$ David C. Korten, seperti yang dikutip Jalaluddin menginvebtaris masalah yang terjadi secara global di abad ke-21, diantaranya: 1) pemulihan lahan kosong yang kritis; 2) mengkonservasi dan mengalokasi sumber-sumber air yang langka; 3) mengurangi polusi udara; 4) memperkuat dan memelihara lahan pertanian kecil; 5) mengurangi tingkat pengangguran yang kronis; 6) jaminan terhadap pemeliharaan hak-hak asasi manusia; 7) penyediaan kredit bagi kegiatan ekonomi berskala kecil; 8) usaha pengurangan persenjataan dan militerisasi; 9) pengawasan terhadap suhu udara secara global; 10) penyediaan tempat tinggal bagi tunawisma; 11) pertemuan yang membutuhkan dua bahasa; 12) pengurangan tingkat kelaparan, tuna aksara, dan tingkat kematian bayi untuk menambah jumlah penduduk; 13) mengurangi tingkat kehamilan remaja; 14) mengatur pertambahan penduduk dan pengaturan perimbangannya; 15) meningkatkan kewaspadaan masyarakat terhadap permasalahan yang menyangkut perkembangan global; 16) peningkatan kewaspadaan terhadap pengrusakan alam; 17) menyediakan fasilitas bagi kesepakatan untuk mengurangi berbagai ketegangan regional yang disebabkan perbedaan rasial, etnis, dan agama; 18) menghilangkan atau membersihkan hujan asam; 19) penyembuhan terhadap korban penyakit AIDS serta mengawasi penyebaran berjangkitnya wabah tersebut; 20) menempatkan kembali atau memulangkan para pengungsi; dan 21) pengawasan terhadap lalu lintas perdagangan alcohol dan penyalahgunaan obat bius. Lihat Ibid., hlm 13-14

${ }^{29}$ M. Amin Syukur, Tasawuf Sosial, Op. Cit., hlm. 21 
beberapa permasalahan yang ada, termasuk merespon fenomenafenomena yang ada dalam masyarakat.

Tasawuf yang aktif, yang humanistic, empiric dan fungsional ini disebut oleh Hamka sebagai tasawuf modern. ${ }^{30}$ Belakangan tasawuf modern ini juga dikenal dengan Tasawuf Positif dan Neosufisme, ${ }^{31}$ berarti bahwa tasawuf ini memandang bahwa tidak perlu meninggalkan capaian-capaian yang positif dari modernisme. Seperti yang lazim dikenal, bahwa krisis spiritual yang terjadi saat ini merupakan dampak dari modernism. Dengan etos hedonisme, materialisme, dan keterpusatan pada teknologi, telah membuat masyarakat kehilangan kesahduan hidup. Akibatnya, ada harga yang lebih mahal dari sekedar keuntungan-keuntungan materi yang selama ini mereka dapatkan, yang menurut Ivan Illich desebut dengan "materialisasi kesadaran". Namun, disamping itu semua, kenyataan bahwa modernisme telah melahirkan banyak hal yang bermanfaat pada manusia tidak dapat diabaikan begitu saja. ${ }^{32}$

Kenyataan bahwa modernisme telah berkembang di dunia ini dengan segala macam dampak negatifnya tidak lantas menjadikan para pelaku harus menutup diri dengan lingkungan sekitar dalam rangka penyucian diri. Model tasawuf masa kini bukan berarti tidak harus menjauhi 'kekuasaan', tapi justru masuk ke tengah-tengah percaturan politik dan 'kekuasaan'. Sebab menjauhinya bisa berarti menunjukkan ketidakberdayaan dan kelemahan. ${ }^{33}$

Fazlur Rahman menyatakan, seperti yang dikutip oleh Amin Syukur, $^{34}$ bahwa tasawuf ini menanamkan disiplin tinggi dan aktif dalam medan perjuangan hidup, baik sosial, politik, dan ekonomi. Pengikutnya dilatih menggunakan senjata dan berekonomi. Gerakannya lebih kepada perjuangan dan juga pembaharuan, sedangkan programnya lebih berada dalam batasan positivisme moral dan kesejahteraan sosial daripada hanya "terkungkung" dalam batasan-batasan spiritual keakhiratan. Coraknya lebih purifikasionis dan lebih aktivis, memberantas penyelewengan moral, sosial dan keagamaan.

${ }^{30}$ H.M. Jamil, Op. Cit., hlm 154

${ }^{31}$ Istilah ini pertama kali diperkenalkan oleh Fazlur Rahman, dalam bukunya Islam.Lihat Ali Maksum, Op. Cit., hlm. 112

${ }^{32}$ Ahmad Najib Burhani, Op. Cit.,hlm. 172

${ }^{33}$ M. Amin Syukur, Tasawuf Sosial, Op. Cit., hlm. 24

${ }^{34}$ Ibid., 
Secara terperinci, terdapat delapan doktrin yang diajarkan dalam Tasawuf Positif, ${ }^{35}$ diantaranya: 1) Allah sebagai Perwujudan Jalal dan Jamal; 2) Insan Kamil sebagai wujud Multidimensi; 3) Dunia dalam Eskatologi Islam; 4) Syariat sebagai unsur Integral Tasawuf; 5) Hikmah sebagai alternative terhadap sufisme anti-intelektual; 6) Alam semesta sebagai tanda-tanda Allah; 7) Akhlak sebagai sasaran tasawuf; dan 8) Amal shaleh sebagai fungsi profetis tasawuf.

\section{a. Allah Sebagai Perwujudan Jalal dan Jamal}

Dalam al-Qur'an dapat kita dapati nama-nama Allah, yang diantaranya kita mengenal dua wajah Allah, yaitu wajah jalal-Nya dan jamal-Nya. Wajah pertama yang sering disebut dengan wajah jalal-Nya merupakan nama-nama Allah yang menunjukkan kebesaran-kebesaran-Nya, keagungan-Nya, kemahaperkasaan-Nya, ketidak-dapat-terbantahan-Nya dan kekuatan-Nya untuk memaksa kita. Oleh para sufi, jalal ini ditujukan atau berkaitan dengan dzat Allah SWT. Kalau kita berbicara Allah dalam hal dzat-Nya, maka hubungan kita sangatlah jauh, di mana Allah adalah dzat yang tidak bisa kita bayangkan. Karenanya, jika kita membayangkan Allah dari segi dzat-Nya, maka yang harus kita lakukan adalah tanzih (pembersihan), membersihkan segala bayangan apapun tentang Allah. Karena Dia tidak bisa kita bayangkan, dan tiada yang semisal Dia sedikit pun, ${ }^{36}$ Dia tidak menyerupai siapapun. ${ }^{37}$ Maka sikap kita adalah membersihkan Allah dari segala yang kita sifatkan. ${ }^{38}$

Wajah Allah yang lain adalah yang menunjukkan keindahan-Nya (jamaliyah). Sachiko Morata, dalam Jalaluddin Rakhmat menerjemahkan jalal dengan His Majesty, dan jamal dengan His Beauty. Jika Jalal berkaitan dengan dzat Allah, maka Jamal berkaitan dengan sifat-sifat Allah. Dengan sifat-sifatnya inilah Allah memperkenalkan diriNya. Diantara sifat-sifatnya Allah yang Jamal itu adalah kasih sayang-Nya, anugerah-Nya, kenikmatan-Nya, karunia-Nya

${ }^{35}$ Ahmad Najib Burhani, Op. Cit., hlm. 179

${ }^{36}$ QS. Al-Syura (42): 11

${ }^{37}$ QS. Al-Ikhlas (112): 4

38 Jalaluddin Rakhmat, Allah dalam Perwujudan Jalal dan Jamal. Dalam Ahmad Najib Burhani, ed., Manusia Modern Mendamba Allah: Renungan Tasawuf Modern, (Jakarta: Penerbit IIman \& Penerbit Hikmah, 2002), hlm. 200 
dan pemeliharaan-Nya. Yang patut menjadi perhatian, ternyata Asma Allah dalam al-Qur'an menunjukkan lebih banyak sisi Jamaliyah Allah daripada sisi Jalaliyah-Nya. Kata sebagian sufi, itu menunjukkan bahwa kasih sayang Allah itu lebih besar daripada kemurkaan-Nya. Bahwa Allah itu lebih cepat ridha dari pada kemurkaan-Nya. ${ }^{39}$

Dari dua wajah Allah ini, maka Tasawuf Positif menghendaki jika pelaku jalan sufi ini tidak hanya mementingkan diri untuk menghindari murka Allah dengan selalu berkontemplasi dalam pengisolasian diri dengan dunia luar, melainkan juga mampu menyebarkan sifat-sifat Allah yang dirasakan oleh sekalian makhluk termasuk manusia. Kasih sayang Allah tidak terbatas bagi siapapun, karenanya seorang sufi juga harus bisa memberikan kasih sayang yang tiada batas kepada siapa saja, termasuk pemeliharaan terhadap makhluk. Sufi yang hanya mementingkan wajah Jalaliyah Allah bisa jadi hanya terjebak dalam dimensi manusia sebagai hamba, dan tidak nampak dimensi lainnya yaitu sebagai khalifah di bumi. Jika memang manusia sebagai "pengganti" Allah di bumi, maka manusia dituntut untuk dapat meniru Allah, meniru bukan berarti menjadi sama dalam dzat-Nya melainkan sifat-sifat Jamaliyah-Nya.

Selain itu, doktrin pertama ini juga menekankan tidak adanya dikotomi antara syariah dan tarekat yang merupakan unsur agama Islam. Menurut tasawuf positif, tiada tasawuf tanpa syariat dan tiada syariat tanpa tasawuf. ${ }^{40}$

b. Insan Kamil Sebagai Wujud Multidimensi

Sebelum dijelaskan maksud dari doktrin kedua dari tasawuf positif ini, perlu kiranya diketahui bagaimana tasawuf tradisional terkait Insan kamil. Menurut tawauf tradisonal, insan kamil adalah manusia yang mampu menangkap sifat-sifat, kehebatan-kehebatan Allah, kemudian tercermin atau teraktualisasikan dalam kehidupannya. Dalam rangka pencapaian pada derajat insan kamil ini. Setidaknya harus melalui beberapa proses: Pertama, tahalli, yakni pengosongan diri manusia dari sifat-sifat, kotoran-kotoran yang memungkinkan menghalangi hadirnya Tuhan dalam diri.

\footnotetext{
${ }^{39}$ Ibid., hlm. 201

${ }^{40}$ Ahmad Najib Burhani, Op. Cit., , hlm. 180
} 
Kedua, takhalli, tahap ini sama dengan menghadirkan Tuhan dalam diri yang sudah dikosongkan. Yang dihadirkan adalah sifat-sifat-Nya. Kalau sifat-sifat itu sudah hadir, maka diri kita akan disifati oleh sifat-sifat Allah. Dalam hadist disebutkan "berakhlaklah Engkau dengan akhlak Tuhan". Dari sinilah kemudian muncul apa yang disebut dengan tajalli (proses ketiga), yakni penampakan sifat-sifat Tuhan dalam diri manusia. Insan kamil adalah orang yang telah melewati tiga tahapan ini. ${ }^{41}$

Pertanyaannya kemudian ialah apakah dengan kehadiran sifat-sifat Tuhan ini menjadikan manusia merasa mampu berlaku seperti Tuhan? Memahami tajalli dengan tanpa adanya koreksi akan menjadikan manusia yang merasa diri sebagai Tuhan. Karenanya, dalam tasawuf positif, doktrin insan kamil sebegai wujud multidimensi adalah manifetasi dari manusia sebagai hamba ('abd) dan manusia sebagai wakil Tuhan di bumi (khalifah fi al-arld). Ini dapat ditemukan dalam sosok Nabi Muhammad SAW., dimana beliau adalah pribadi yang mengutamakan kedekatan dan hubungan cinta antara manusia dengan Allah. Namun, pada saat yang sama, ia melakukan transformasi dalam masyarakat dalam bidang sosial, ekonomi, politik dan sebagainya. ${ }^{42}$

\section{c. Dunia Dalam Eskatologi Islam}

Maksudnya, bahwa tasawuf positif percaya bahwa kehidupan dunia merupakan bagian dari fitrah eksistensi manusia, yang di lain sisi juga merupakan sarana menuju kebahagiaan di akhirat. Tasawuf positif percaya bahwa dunia adalah bagian penting dari eksistensi manusia sebagai hamba Allah. ${ }^{43}$ Oleh karenanya perjalanan kehidupan di dunia di jadikan sebagai sarana infestasi di akhirat kelak. Sehingga memberikan motifasi kepada para sufi untuk memaksimalkan potensi keduniaan dalam mempersiapkan kehidupannya di akhirat.

${ }^{41}$ Komaruddin Hidayat. Insan Kamil sebagai Makhluk Multidimensi. Dalam Ahmad Najib Burhani, ed., Manusia Modern Mendamba Allah: Renungan Tasawuf Modern, (Jakarta: Penerbit IIman \& Penerbit Hikmah, 2002), hlm. 218

${ }^{42}$ Ahmad Najib Burhani, Op. Cit., hlm. 180

${ }^{43}$ Ibid., 


\section{d. Syariat Sebagai Unsur Integral Tasawuf}

Selama ini diasumsikan bahwa syariat dan tasawuf sebagai dua sisi yang bertentangan. Fanatisme syariat (fuqaha) memandang bahwa tasawuf adalah haram. Sementara para pelaku tasawuf tidak kalah mengkritik para fuqaha yang hanya mementingkan keformalitasan saja.

Sebenarnya, antara syariat dan tasawuf tidak harus dipertentangkan satu sama lainnya. Karena memang keduanya memiliki lingkup yang berbeda, sehingga ketika dipaksa untuk mengonfrontasikan keduanya dengan maksud mencari kesamaan, maka yang didapati adalah pertentangan. Tasawuf lebih menempati wilayah batin atau hati yang tak dapat ditembus pancaindera. Sementara syariat bersifat lahiriah atau legal-formal, sehingga dapat ditangkap mata telanjang. $^{44}$

Tasawuf positif menghendaki adanya integrasi tasawuf dan syariat. Karena penguatan aspek tasawuf akan menjadi dinamisator bagi jiwa seseorang. Kehadiran tasawuf akan mampu memicu tsaurah ruhiyya (revolusi jiwa) dan menjadi spirit bagi pelakunya. Sebaliknya, syariat ibarat jalan yang akan dilalui sufi untuk berevolusi. Asumsinya, jika syariat adalah jalan, maka jalan yang terlalu banyak hambatan dan lobangnya tentu akan menghambat perjalanan menuju terminal terakhir. ${ }^{45}$

e. Hikmah Sebagai Alternatif Terhadap Sufisme AntiIntelektual

Tasawuf dan intelektualitas sering dipahami secara dikotomis. Ilmu tasawuf sering dipandang lebih menitikberatkan pada aspek intuisi, ilham atau bisikan hati yang tidak jarang tak sesuai dengan rasionalitas. Sementara itu, kebalikan dari tasawuf yang mengabaikan peran akal, disiplin ilmu lainnya seperi filsafat sangatlah patuh terhadap prinsip-prinsip rasionalitas yang terkadang harus "berhadapan" dengan teks al-Qur'an atau Hadits yang menentangnya. ${ }^{46}$

${ }^{44}$ Said Agil Siradj, Op. Cit., hlm. 248

${ }^{45}$ Ibid.,

${ }^{46}$ Husein Shahab, Hikmah sebagai Alternatif dari Sufisme Anti Intelektual. Dalam Ahmad Najib Burhani, ed., Manusia Modern Mendamba Allah: Renungan Tasawuf Modern, (Jakarta: Penerbit IIman \& Penerbit Hikmah, 2002), hlm. 265 
Namun, tasawuf positif tidak memandang keduanya sebagai sesuatu yang bertentangan. Menurut tasawuf positif, rasionalitas dan intelektualitas adalah sendi pencarian kebenaran, termasuk di dalamnya kebenaran spiritual. Adalah hikmah, suatu aliran pemikiran yang ada dalam khazanah intelektual Islam yang menggabungkan rasionalisme filsafat dengan metode pencerahan spiritual. ${ }^{47}$

\section{f. Alam Semesta Sebagai Tanda-Tanda Allah}

Dewasa ini, kita telah dihadapkan pada dua paham ekstrim yang saling bertentangan, yaitu: "positivisme" sekuler dan spiritualisme panteistik. Positivisme hanya memandang real benda-benda yang bisa diambil secara positif, yakni secara indrawi. Positivisme inilah yang kemudian dijadikan pijakan untuk ilmu (sains). Tentu saja dari sudut pandang tasawuf positif, pandangan ilmiah yang didasarkan pada positivisme ini sangatlah distorsif. Karena alam semesta bukanlah satu-satunya realitas, melainkan "tanda-tanda" saja dari Realitas Sejati yang ada dibalik fenomena positif. Pandangan sains ini berdampak pada pengkajian alam yang dilihat bukan sebagai "tanda-tanda" atau "jejak-jejak" kebijaksanaan Tuhan, melainkan sebagai realitas independent yang dilepaskan dari hubungan apa pun dengan Tuhan. ${ }^{48}$

Sementara itu, kebalikan dari positivisme adalah panteistik. Yang memandang bahwa alam itu berbeda dari petanda, yaitu Allah, melainkan dipandang sebagai "cermin" Allah, yang dikatan "walaupun berbeda, tetapi tidak lain daripada" Allah itu sendiri. Dalam pandangan spiritualisme ekstrim ini, alam dipandang sebagai manifestasi (tajalli) Allah, sebagai realisasi dari Tuhan. Pandangan ini pada akhirnya manjadikan alam dan Tuhan sulit dibedakan, karena kecenderungan menyamakan keduanya. Alam adalah

${ }^{47}$ Ahmad Najib Burhani, Op. Cit., hlm. 181

${ }^{48}$ Mulyadi Kartanegara, Alam Semesta sebagai Cermin Allah. Dalam Ahmad Najib Burhani, ed., Manusia Modern Mendamba Allah: Renungan Tasawuf Modern, (Jakarta: Penerbit IIman \& Penerbit Hikmah, 2002), hlm. 275-277 
manifestasi Tuhan, dan karena itu ia tidak lain daripada Tuhan itu sendiri yang memanifestasikan. ${ }^{49}$

Dua pandangan tersebut kemudian oleh tasawuf positif dijembatani. Karena dalam pandangan tasawuf positif, alam bukanlah Tuhan dan tidak pula memandangnya sebagai realitas independen yang tidak punya kaitan apapun dengan realitas yang lebih tinggi. Bagi tasawuf positif, alam adalah tanda-tanda Tuhan. la adalah petunjuk dengan mana kita bisa mengenal Tuhan. ${ }^{50}$

g. Akhlak Sebagai Sasaran Tasawuf

Ada yang menganggap bahwa tujuan tasawuf adalah untuk moral elaboration perfection, kesempurnaan etika. Karena tanpa kesempurnaan etika akan sulit untuk dapat beranjak lebih jauh lagi. Jadi, salah satu landasan tasawuf adalah kesempurnaan etika. ${ }^{51}$

Dalam al-Qur'an dapat kita lihat bahwa dasar dari tasawuf adalah akhlak (etika). Apabila kita berakhlak yang tinggi, maka kita sebenarnya dekat dengan Tuhan. Dalam alQur'an disebutkan, Qaulun ma'rûfun wa maghfiratun min shadaqatin yatba'uhâ adzâ (QS. Al-Baqarah: 263), tutur kata yang indah dan memohon maaf itu lebih mulia di mata Allah daripada orang yang menyantuni orang lain tetapi tidak menghindarkan dari berbuat kejelekan. Untuk apa menyedekahkan uang sebanyak satu juta jika dirinya sendiri masih kekurangan. Bagi Allah, lebih bagus memohon maaf daripada memberi tapi lupa berakhlak. Semisal, bahwa kita (bangsa Indonesia) telah mempunyai konsep yang bagus seperti GBHN (Garis Besar Haluan Negara). Tetapi who is behind the good, siapa yang menjalankan GBHN itu. Jadi kalau orang ditanya konsep tentang pemilu, banyak orang mau membuatkan konsep yang bagus. Yang penting siapa yang menjalankan konsep itu. Karena sebagus apapun konsep yang dibuat kalau yang menjalankan bobrok akhlaknya, bisa ditafsirkan keliru. Jadi ruh Islam itu adalah terdapat pada akhlak. Kalau akhlak kita benar, insyaallah

${ }^{49}$ Ibid., hlm. 277

${ }^{50}$ Ibid., hlm. 278

51 Alwi Shihab, Akhlak sebagai Sasaran Tasawuf. Dalam Ahmad Najib Burhani, ed., Manusia Modern Mendamba Allah: Renungan Tasawuf Modern, (Jakarta: Penerbit IIman \& Penerbit Hikmah, 2002), hlm. 286 
semuanya akan jalan benar. ${ }^{52}$ Inilah yang juga menjadi titik tolak bagi sufi untuk menjalankan fungsinya sebagai manusia.

\section{h. Amal Shaleh Sebagai Fungsi Profetis Tasawuf}

Inti ajaran tasawuf adalah dapat dekat dengan Tuhan, dan ini hanya mungkin terwujud dengan usaha yang seoptimal mungkin mewujudkan ajaran-Nya dalam seluruh tatanan kehidupan dengan wujud amal shaleh. Sebab amal shaleh merupakan indikator utama ketakwaan. ${ }^{53}$

Amal shaleh ini bisa diartikan sebagai setiap perbuatan dalam memperbaiki lingkungan hidup kita. Melakukan amal shaleh adalah sama dengan melakukan ishlah atau reformasi. Tasawuf positif melihat amal shaleh sebagai satu-satunya tolok ukur bagi keberhasilan seseorang menjalani tasawuf. Kesimpulannya adalah tidak ada tasawuf tanpa amal shaleh, menyantuni dhuafa, kasih saying terhadap sesama manusia, menolak tindakan kotor dan keji, peduli pada lingkungan dan sebagainya. ${ }^{54}$

\section{Tasawuf Positif Dalam Kepemimpinan}

Pemimpin dalam makna bahasa terdapat isyarat yang menarik, yang intinya ialah posisi pemimpin berada di depan agar menjadi petunjuk bagi anggotanya dalam kebaikan dan menjadi pembimbing mereka kepada kebenaran. Pemimpin rumah tangga bertanggung jawab atas pendidikan anak-anaknya. Pemimpin organisasi akan bertanggung jawab atas jalannya organisasi dan kesuksesannya. Guru bertanggungjawab atas pendidikan pada muridnya. ${ }^{55}$ Definisi ini pun tak mengecualikan pemimpin-pemimpin pemangku kebijakan pendidikan dan pemimpin-pemimpin lembaga pendidikan di bawahnya.

Yang perlu menjadi perhatian adalah bahwa pemimpin ini adalah ibarat seorang nahkoda yang bertanggung jawab atas para penumpang kapal yang sedang berlayar di laut lepas. Ketika nahkoda

${ }^{52}$ Ibid., hlm. 292

${ }^{53}$ Didin Hafidhuddin, Amal Shaleh sebagai Fungsi Profetis Tasawuf. Dalam Ahmad Najib Burhani, ed., Manusia Modern Mendamba Allah: Renungan Tasawuf Modern, (Jakarta: Penerbit IIman \& Penerbit Hikmah, 2002), hlm. 315

${ }^{54}$ Ahmad Najib Burhani, Op. Cit., hlm. 182

${ }^{55}$ Thariq Muhammad As-Suwaidan dan Faishal Umar Basyarahil, Melahirkan Pemimpin Masa Depan, terj. M. Habiburrahim, (Depok: Gema Insani Press, 2005), hlm. 9 
ini menjalankan tugasnya dengan benar, maka tujuan yang dituju oleh kapal itu akan dicapai. Namun jika tidak dapat menjalankan tugasnya dengan benar, maka sudah barang tentu ini akan membahayakan semua penumpang. Dan nampaknya saat ini kepemimpinan di sekitar kita menunjukkan kenyataan yang cukup menggetirkan, baik itu kepemimpinan di tingkat lokal, regional maupun nasional. Makin sedikit jumlahnya pemimpin yang benarbenar tahu tugas dan tanggungjawabnya. Makin sedikit nahkoda yang tahu cara menjalankan dan mengarahkan kapalnya menuju tempat yang dituju. Kepemimpinan secara global saat ini dihadapkan pada beberapa krisis yang jika dibiarkan maka bukan tidak mungkin akan menimbulkan krisis yang lebih kompleks lagi. Diantara krisis kepemimpinan itu adalah krisis keterbelakangan, krisis efektifitas, krisis kesadaran, dan krisis lemahnya kinerja pemimpin.

\section{a. Kriris Keterbelakangan}

Krisis ini adalah ketika pemimpin yang kehilangan elemen-elemen utama untuk memimpin. Meskipun ada metode-metode yang bagus dalam al-Qur'an dan Sunnah. Namun problemnya adalah siapakah yang akan melaksanakannya? ${ }^{56}$

Kenyataan bahwa banyak pemimpin yang mengaku beragama dan juga melakukan rutinitas keagamaan ternyata juga tetap berlaku dlolim kepada yang dipimpinnya adalah bukti bahwa kepemimpin kita saat ini mengalami krisis keterbelakangan. Orientasi kepemimpinan bukan lagi menjadi penunjuk sesuatu yang benar dan membimbing pada kebenaran, namun telah berubah menjadi bagaimana ia mampu menumpuk materi sebanyak mungkin dalam kepemimpinannya itu.

\section{b. Krisis Efektifitas}

Kelemahan untuk memberikan pengaruh dan pembentukan pikiran, meluruskan nilai-nilai yang rusak dan menggantikannya dengan nilai-nilai yang benar. Ini adalah krisis kepemimpinan yang selanjutnya. ${ }^{57}$ Ketika muncul seorang pemimpin yang benar-benar menjalankan tugasnya menunjukkan dan membimbing pada kebenaran, ada saja rintangan yang itu sengaja atau tidak sengaja diciptakan oleh

\footnotetext{
${ }^{56}$ Ibid.,hlm. 14

${ }^{57}$ Ibid.,hlm. 16
} 
rekan-rekannya. Sehingga dalam menjalankan kewajibannya, ia tidak hanya dihadapkan masalah-masalah di lapangan namun juga masalah dengan orang-orang di sekitarnya yang enggan berlaku jujur.

\section{c. Krisis Kesadaran}

Ketika kesadaran sebagai seorang pemimipin -dimana beban tanggung jawab siapa saja yang dipimpinnya- hilang, maka cinta kedudukan dan jabatan akan berusaha saling menguasai hati manusia. ${ }^{58}$ Jual beli kekuasan yang marak saat ini adalah fakta tak terbantahkan atas sudah pudarnya kesadaran seorang pemimpin atas tanggungjawab yang ia pikul. Padahal jika kita membuka sejarah kekhalifahan, kita akan melihat betapa Umar bin Khattab begitu khawatir bahwa ia tidak bisa mempertanggungjawabkan kepemimpinannya kelak. la sadar bahwa posisi sebagai amirul mukminin bukanlah hal yang mudah. Namun kenyataan yang terjadi saat ini sebaliknya, kepemimpinan layaknya hidangan lezat yang diperebutkan.

\section{d. Krisis Lemahnya Kinerja Pemimpin}

Salah satu krisis yang dilewati oleh sebuah organisasi secara umum adalah lemahnya kinerja pemimpin, dan ini mempunyai efek dan pengaruh di semua bidang. Lebih dari itu, masalah yang kita hadapi adalah lemahnya mental diri kita sendiri. Kelemahan kita dalam mengenal identitas kita, dan kelemahan dalam mengenal Tuhan. ${ }^{59}$ Tuhan dalam persepsi kita menjadi banyak. Allah yang ada dalam benak kita ketika berada di masjid berbeda ketika kita sedang berada di pasar, di kantor, di swalayan dan sebagainya.

Ibarat penyakit, krisis kepemimpinan tersebut makin hari semakin parah. Nampak pula bahwa syariah agama, yang dalam hal ini aspek lahir agama seperti shalat, puasa dan sebagainya tak lagi mampu membendung krisis tersebut, maka harapan selanjutnya ada pada tasawuf yang merupakan aspek kebatinan agama. Namun apa jadinya jika ternyata tasawuf juga enggan masuk pada keduniawiaan ini yang banyak mengandung kehinaan. Dunia dengan segala krisisnya ini akan menjadi ibarat kolam yang begitu kotor, dan apakah

\footnotetext{
${ }^{58}$ Ibid., hlm. 17

${ }^{59}$ Ibid.,
} 
mungkin seorang pengamal tasawuf yang hendak mensucikan diri dari kotoran-kotoran dunia justru terjun ke dalam kolam yang kotor itu?

Meskipun persepsi yang ada selama ini tentang tasawuf yang tidak begitu terpaku pada dunia, tidak demikian dengan tasawuf positif atau Neosufism. Tidak bisa dipungkiri bahwa krisis kepemimpinan yang terjadi selama ini salah satunya disebabkan oleh gersangnya batin dari seorang pemimpin. Agama dimaknai sebagai laku dlohir, ketika ia tetap shalat, tetap puasa, tetap berhaji, bersedekah dan lainnya. Namun itu tidak berimbas pada laku kesehariannya, karena tetap saja seberapa ia bersedekah ia tetap saja melakukan korupsi, sebanyak apapun ia berhaji, ia tetap mengacuhkan yang dipimpinnya dari ketidaksejahteraan, keterpurukan, dan sebagainya.

Jika mengacu pada doktrin tasawuf positif, maka seorang pemimpin harusnya mempunyai kriteria sebagai berikut:

\section{a. Mempunyai Sifat Jamal}

Sesuai dengan doktrin pertama tasawuf positif, bahwa Allah adalah perwujudan sifat jalal dan jamal. Sifat jalal terkait kekuasaan-Nya, sifat jamal-Nya terkait dengan luasnya karunia dan kasih sayang-Nya. Ini juga bisa dijadikan acuan bagi seorang pemimpin, dimana ia dituntut untuk lebih mengedepankan kasih sayangnya dari pada mengedepankan kekuasannya atas apa yang dipimpin. Bukankah Allah juga demikia? Dia lebih cepat ridlo-Nya daripada murka-Nya? Maka, akan sangat aneh jika kita sebagai ciptaan-Nya berlaku sebaliknya, yang sedikit-sedikit murka. Lebih dari itu, jamal yang mempunyai arti indah juga bisa diartikan sebagai pembawa ketenangan dan kenyamanan. Jadi, pemimpin itu bukannya menjadi sosok yang tiran, yang menakutkan, namun yang membawa rasa nyaman bagi yang dipimpinnya, seperti yang dicontohkan oleh kepemimpinan Nabi Muhammad SAW.

\section{b. Sadar Akan Tugasnya Sebagai Hamba dan Khalifah}

Bahwa pemimpin harus menyadari sepenuhnya bahwa kepemimpinannya akan dipertanggungjawabkan kelak dihadapan Allah SWT. Keasadaran ini penting untuk menjadikannya berhati-hati dalam melaksanakan tugas 
kepemimpinannya. Selain bahwa ia memimpin, status kehambaannya pun tidak lantas hilang. la tetap mempunyai kewajiban beribadah kepada Tuhan. Ibadah ini tidak hanya berhenti pada batas ibadah secara formal saja, namun juga harus mempunyai dampak pada laku kesehariannya. Akhirnya, dalam tugasnya sebagai khalifah juga mempunyai keterkaitan dengan kehambaan-Nya pada Tuhan yang menitahkan ia sebagai pengganti-Nya di bumi. Jika seorang pemimpin memiliki kesadaran ini, maka ia tidak akan berani melakukan kedloliman dalam kepemimpinanya.

\section{c. Kesederhanaan}

Sederhana di sini dalam hal memandang dunia, tapi bukan berarti tidak membutuhkan sama sekali terhadap dunia. Pemimpin harus menyadari bahwa dunia adalah bagian dari eksistensi manusia. Sudah banyak ditemukan fakta bahwa karena tidak terpenuhinya kebutuhan dunia menjadikan seseorang melakukan kejahatan yang kejahatan ini membuat suasana menjadi tidak nyaman. Di sinilah kemudian peran seorang pemimpin, ia harus mampu menciptakan lingkungan kerja yang nyaman dan kondusif bagi yang ia pimpin. Karena bagaimana pun juga, kenyataan bahwa saat ini kita hidup di dunia ini bukan hanya hidup saja, namun juga membutuhkan banyak hal. Selain itu, pemimpin yang disebutkan sebagai penunjuk dan pembimbing kebenaran menjadi teladan juga bagi yang dipimpinnya.

\section{d. Mementingkan Asas Keseimbangan}

Ada pemimpin yang begitu mementingkan formalitas beragama, akhirnya mengeluarkan peraturan-peraturan yang belandaskan agama yang ia anut atau berdasarkan kepentingan pribadi dan kelompoknya. Ada juga pemimpin yang begitu mementingkan nilai-nilai agama sehingga lupa akan pentingnya formalitas agama. Akhirnya ia melarang adanya ritual kegamaan yang bersifat publik, pemakaian simbol-simbol agama juga tak diperbolehkan. Pemimpin dituntut bisa mengakomodasi aspek syariah dan juga aspek kebatinan suatu agama. Tidak seharusnya dalam kepemimpinannya ia mengedepankan dlohir daripada batin dan sebaliknya. Jika di tarik dalam dunia pendidikan pun tak seharusnya pemimpin itu mengutamakan hitam di atas putih 
saja melainkan juga melihat kompetensi dan profesionalitas orang-orang yang dipimpinnya.

Selain itu, pemimpin juga tidak seharusnya tampil sebagai sosok yang terlalu intelektual, dalam arti mementingkan rasional, dan juga tidak mementingkan laku spiritual saja. Mementingkan rasionalitas saja akan membawanya pada kegersangan spiritual, sedangkan ketika kebatinan lebih ditonjolkan maka akan menjadi pemimpin yang menjadikan organisasi atau lembaganya tertinggal dari perkembangan zaman.

e. Berkahlak Mulia

Berakhlak mulia kepada semuanya. Semuanya di sini tidak terbatas pada manusia, melainkan kepada semua makhluk yang hidup di bawah kekuasaannya. Hewan, tumbuh-tumbuhan dan juga lingkungan sekitar juga harus menerima perlakuan yang didasarkan pada akhlak mulia seorang pemimpin. Adanya pemimpin yang berlaku seenaknya demi kepentingan pribadi, kelompoknya atau beberapa orang saja adalah satu contoh akhlak yang tercela yang ditunjukkan seorang pemimpin dengan pragmatisme yang menjadi orientasinya.

Pada akhirnya, akhlak mulia ini memunculkan perilaku yang mulia pula (amal shaleh). Perilaku yang baik kepada sesama manusia, kepada hewan, tumbuhan, dan lingkungan. Dan karena seorang pemimpin, maka ia tidak hanya berhenti pada bersikap yang baik saja, namun juga bagaimana ia mampu menjadikan orang-orang yang berada dalam kepemimpinannya dapat berperilaku demikian juga. Bukankah pemimpin adalah penunjuk, pembimbing dan sosok yang menjadi anutan? Maka selain ia berperilaku baik, ia juga harus menjadikan yang ia pimpin berlaku seperti itu juga.

Inti dari semua kriteria di atas adalah kesadaran penuh dari seorang pemimpin bahwa semua yang ia kerjakan dalam kepemimpinan akan dipertanggungjawabkan kelak di akhirat, sehingga dengan kesadaran ini seorang pemimpin akan merasa takut untuk berbuat dlolim dalam kepemimpinanya. Menarik jika kita merenungkan perkataan Umar ibnul Khattab r.a. berikut ini:

"Demi Tuhan! Aku tidak bisa shalat dan tidur dengan tenang. Sungguh aku membaca sebuah surah al-Qur'an, namun aku 
tidak tahu apakah aku ada di awalnya atau di akhirnya, karena kesusahanku memikirkan manusia sejak aku menerima berita ini," yaitu sejak aku memangku jabatan Amirul Mukminin. ${ }^{60}$

Apa yang disampaikan oleh Umar ibnul Khattab ini bukan berarti ia pesimis dengan kemampuannya dalam memimpin, namun lebih kepada kekhawatiran jika ia tidak mampu menjalankan tugas berat yang ia terima. Keasadaran ini pada akhirnya membuat Umar ibnul Khattab menjadi pemimpin yang sangat adil dan bijaksana.

\section{KESIMPULAN}

Tasawuf positif merupakan titik balik dari tasawuf konservatif. Jika tasawuf konservatif, dalam upayanya mendekatkan diri pada Tuhan adalah dengan melakukan pengasingan diri dari dunia luar dan berkontemplasi. Maka tasawuf positif justru mengehendaki pengamalanya terjun dalam keduniaan dengan segala pernak-perniknya. Jika tasawuf konservatif mengesankan tasawuf itu melangit, maka tasawuf positif memberikan kesan bahwa tasawuf itu harus membumi. Harus nampak dalam segala kehidupan sosial, dan juga ikut andil dalam penyelesaian permasalahan dunia.

Dalam tasawuf positif sendiri terdapat beberapa doktrin, diantaranya: Allah sebagai Perwujudan Jalal dan Jamal; Insan Kamil sebagai Wujud Multidimensi; Dunia dalam Eskatologi Islam; Syariat sebagai Unsur Integral Tasawuf; Alam Semesta sebagai Tanda-tanda kekuasaan Allah; Akhlak sebagai Sasaran Tasawuf; dan Amal Shaleh sebagai Fungsi Profetis Tasawuf. Dan ketika dihubungkan dalam konteks kepemimpinan, maka akan memunculkan kriteria seorang pemimpin sebagai berikut: Mempunyai sifat jamal; Sadar akan tugasnya sebagai Hamba dan Khalifah; Mementingkan asas keseimbangan; dan Berkahlak mulia.

\section{DAFTAR PUSTAKA}

As-Suwaidan, Thariq Muhammad dan Faishal Umar Basyarahil. 2005. Melahirkan Pemimpin Masa Depan. Terj. M. Habiburrahim. Depok: Gema Insani Press.

Bagir, Haidar. 2001. Antara Tasawuf Eksesif dan Tasawuf Positif (Pengantar). Dalam Ahmad Najib Burhani. 2001. Sufisme Kota. Jakarta: Serambi Ilmu Semesta.

\footnotetext{
${ }^{60}$ Ibid., hlm. 16
} 
EVALUASI, 3(1), Maret 2019, ISSN 2580-3387 (print) I ISSN 2615-2886 (online) http://doi.org/10.32478/evaluasi.v3i1.225

2002. Manusia Modern Mendamba Allah (Pengantar). Dalam Ahmad Najib Burhani. 2002. Manusia Modern Mendamba Allah, Renungan Tasawuf Positif.Jakarta: Penerbit IIMan dan Penerbit Hikmah.

Chittick, William C. 2002. Tasawuf di Mata Kaum Sufi, terj. Zainul Am. Bandung: Mizan.

Clarke, H. Wilberforce. 1998. Pendahuluan. (13-31). Dalam Syihabuddin Umar ibn Muhammad Suhrawardi. 1998. 'Awarif al-Ma'arif: Sebuah Buku Daras Klasik Tasawuf. terj. Ilma Nugrahani Ismail. Bandung: Pustaka Hidayah.

Hafidhuddin, Didin. 2002. Amal Shaleh sebagai Fungsi Profetis Tasawuf. (315322). Dalam Ahmad Najib Burhani, ed. 2002. Manusia Modern Mendamba Allah: Renungan Tasawuf Modern. Jakarta: Penerbit IIman \& Penerbit Hikmah.

Hidayat, Komaruddin. 2002. Insan Kamil sebagai Makhluk Multidimensi. (215225). Dalam Ahmad Najib Burhani. ed. 2002.Manusia Modern Mendamba Allah: Renungan Tasawuf Modern. Jakarta: Penerbit IIman \& Penerbit Hikmah.

Ibrahim, Muhammad Zaki. 2002. Tasawuf Salafi, Menyucikan Tasawuf dari Noda-noda. Jakarta: Hikmah.

Jalaluddin. 2012. Psikologi Agama: Memahami Perilaku dengan Mengaplikasikan Prinsip-prinsip Psikologi. cet. 16. Jakarta: Rajagrafindo Persada.

Kamal, Zainul. 2002. Tasawuf dan Tarekat: Ajaran Esoterisme Islam. (11-20). Dalam Ahmad Najib Burhani, ed. 2002. Manusia Modern Mendamba Allah: Renungan Tasawuf Modern. Jakarta: Penerbit IIman \& Penerbit Hikmah.

Kartanegara, Mulyadi. 2002. Alam Semesta sebagai Cermin Allah. (275-282). Dalam Ahmad Najib Burhani, ed. 2002. Manusia Modern Mendamba Allah: Renungan Tasawuf Modern. Jakarta: Penerbit IIman \& Penerbit Hikmah.

Maksum, Ali. 2003. Tasawuf sebagai Pembebasan Manusia; Telaah Signifikansi Konsep "Tradisionalisme Islam" Sayyed Hossein Nasr. Yogyakarta: Pustaka Pelajar. 
EVALUASI, 3(1), Maret 2019, ISSN 2580-3387 (print) I ISSN 2615-2886 (online) http://doi.org/10.32478/evaluasi.v3i1.225

Mubarak, Achmad. 2002. Relevansi Tasawuf dengan Problem Kejiwaan Manusia Modern. (165-180). Dalam Ahmad Najib Burhani, ed. 2002. Manusia Modern Mendamba Allah: Renungan Tasawuf Modern. Jakarta: Penerbit IIman \& Penerbit Hikmah.

Muhayya, Abdul. 2001. Peranan Tasawuf dalam Menanggulangi Krisis Spiritual. Dalam Bima Bayu A. 2001. Tasawuf dan Krisis.Yogyakarta: Pustaka Pelajar.

Najib Burhani, Ahmad. 2001. Sufisme Kota. Jakarta: Serambi Ilmu Semesta.

Rakhmat, Jalaluddin. 2002. Allah dalam Perwujudan Jalal dan Jamal. (199208). Dalam Ahmad Najib Burhani, ed. 2002. Manusia Modern Mendamba Allah: Renungan Tasawuf Modern. Jakarta: Penerbit IIman \& Penerbit Hikmah.

Shahab, Husein. 2002. Hikmah sebagai Alternatif dari Sufisme Anti Intelektual. (265-273). Dalam Ahmad Najib Burhani, ed. 2002. Manusia Modern Mendamba Allah: Renungan Tasawuf Modern. Jakarta: Penerbit IIman \& Penerbit Hikmah.

Shihab, Alwi. 2002. Akhlak sebagai Sasaran Tasawuf. (283-303). Dalam Ahmad Najib Burhani, ed. 2002. Manusia Modern Mendamba Allah: Renungan Tasawuf Modern. Jakarta: Penerbit IIman \& Penerbit Hikmah.

Sholikhin, Muhammad. 2004. Tasawuf Aktual. Semarang: Pustaka Nuun.

Siradj, Said Agil. 2002. Syariat sebagai Unsur Integral Tasawuf. (243-253). Dalam Ahmad Najib Burhani. ed. 2002.Manusia Modern Mendamba Allah: Renungan Tasawuf Modern. Jakarta: Penerbit IIman \& Penerbit Hikmah.

Suyuti, Ahmad. 2002. Percik-Percik Kesufian. Bandung: Penerbit Pustaka Hidayah.

Syukur, M. Amin. 2003. Tasawuf Kontekstual; Solusi Problem Manusia Modern.Yogyakarta: Pustaka Pelajar. . 2004. Tasawuf Sosial. Yogyakarta: Pustaka Pelajar. 